\title{
$O$ assédio na atualidade e seus jogos de verdade
}

Joel Birman ${ }^{\star}$

\begin{abstract}
RESUMO
Este trabalho tem o objetivo de apresentar e discutir a hipótese de que o uso freqüente da palavra assédio hoje está ligado às condições históricas e sociais de possibilidade nas quais se engendram novos jogos de linguagem a partir desta palavra. Disso resulta a disseminação de outros jogos de verdade. Como conclusão indico que o crescimento na utilização desse significante e a imprecisão aparente que faz parte do seu campo semântico podem então ser interpretados no contexto das transformações de poder e da perda da soberania do Estado na atualidade.
\end{abstract}

Palavras-chave: Poder. Jogos de verdade. Formas de subjetivação.

\section{Harassment today and its truth games}

\begin{abstract}
The aim of this essay is to support the hypothesis that today's frequent use of the word harassment is linked with the social and historical conditions in which new language games derive from this word. As a consequence there is a dissemination of other truth games. The excessive use of this signifier and the imprecision in its semantic field can be interpreted in the current context of a power shifting and the State's loss sovereignty.
\end{abstract}

Keywords:Power. Truth. Subjectivation.

^ Mestre em filosofia pela Pontifícia Universidade Católica do Estado do Rio de Janeiro, Doutor em filosofia pela USP, Pós-Doutorado em psicanálise na Universidade Paris VII, membro do Espace Analytique e Pesquisador e Consultor do CNPq. Psicanalista e professor do Instituto de Psicologia da Universidade Federal do Rio de Janeiro e do Instituto de Medicina Social da Universidade do Estado do Rio de Janeiro. Endereço: Rua Marquês de São Vicente, 512 - apto. 902 Gávea - Rio de Janeiro 22451-041. E-mail: regmarchese@ terra.com.br 


\section{ENTRE JOGOS DE VERDADE E FORMAS DE SUBJETIVAÇÃo}

A palavra assédio ganha hoje franca notoriedade pública. Isso aconteceu bem recentemente na nossa tradição, de forma que aquela passou a designar não apenas acontecimentos novos, mas também situações que eram anteriormente denominadas de maneira diferente nas práticas linguageiras. Em decorrência disso, o significante assédio foi desmesuradamente inflacionado no imaginário contemporâneo. Com efeito, nunca se falou tanto em assédio como nos últimos tempos, como se pode reconhecer facilmente não apenas pela leitura de jornais e revistas, sejam estes populares ou eruditos, como também pela incorporação fácil dessa palavra no discurso cotidiano para descrever e qualificar certas experiências presentes no espaço social.

No entanto, o próprio funcionamento dessa lógica inflacionária, que regula a sua franca utilização discursiva, provoca, em contrapartida, uma imprecisão evidente no campo semântico da palavra assédio, de maneira que o sentido em pauta torna-se quase evanescente e sem fronteiras bem-traçadas. Se quase tudo pode ser denominado de assédio, com efeito, fica bastante difícil dizer que sentido e que conceito estão em causa no uso ostensivo deste significante.

Constitui-se, assim, um verdadeiro paradoxo entre o significante e o campo semântico da palavra o assédio, o que evidencia a imprecisão conceitual no seu uso discursivo. Fala-se muito e até excessivamente de algo, mas freqüentemente não se sabe muito bem o que se diz. Tudo isso se reflete e se dissemina também no campo das ciências sociais, é claro, que se embaralha claramente na interpretação desse conceito. É neste contexto que se inscreve a razão deste colóquio organizado sobre o assédio, para que se possa avançar decididamente na sua compreensão conceitual, pela indicação e superação de alguns de seus impasses. Digo "avançar" - bem entendido - não solucionar, supondo que as contribuições promovidas por este debate nos possibilitem melhor compreender o que está aqui efetivamente em questão.

Nessa perspectiva, proponho inicialmente, então, que a categoria de "jogo de linguagem", enunciada por Wittgenstein (1961) nas "Investigações filosóficas", possa ser um rico instrumento de trabalho para que se possa superar esta disjunção entre a inflação do significante assédio e a suposta imprecisão do seu campo semântico. Isso porque esta direção teórica e metodológica nos permite um desvio do discurso conceitual e epistemológico, no sentido estrito do termo, que nos obriga a considerar, assim, a leitura do conceito a partir das práticas linguageiras que estão presentes no imaginário social. Pelo destaque conferido aos contextos de produção do enunciado em pauta, nos registros social e histórico, poderíamos melhor apreender os valores que estão em questão na proliferação da palavra assédio, assim como na multiplicação de seu campo semântico.

Em seguida, propondo ainda que a categoria de jogo de linguagem seja considerada no contexto teórico de sua interpretação por Foucault (1994), que cunhou a categoria de "jogo de verdade". Nessa torção conceitual, Foucault (1974) procurou indicar como tais jogos de linguagem são produtores de verdade no 
espaço social. Isso porque esses jogos se inscrevem efetivamente no campo imantado do confronto de forças que perpassam os embates de poder presentes no espaço social (FOUCAULT, 1976). Seriam esses confrontos de força, que constituem efetivamente a gramática do poder, que delineariam os contextos histórico e social que regulariam os processos de produção de verdade. Com isso, os jogos de verdade seriam as condições concretas de possibilidade para as novas "formas de subjetivação" que se disseminam nos agentes sociais.

Retomando, então o que se disse acima, podemos relançar a nossa questão enunciando que se o uso da palavra assédio se disseminou hoje a olhos vistos, sem qualquer dúvida, isso indica seguramente que se constituíram na atualidade as condições histórica e social de possibilidade para a constituição de novos jogos de linguagem sobre tal palavra. Em decorrência disso, multiplicaram-se os contextos para a disseminação de outros jogos de verdade sobre o assédio. A inflação no uso desse significante e a aparente imprecisão presente no seu campo semântico podem ser melhor interpretadas assim neste contexto teórico.

Para isso, no entanto, a problemática do poder deve ser devidamente destacada na sua leitura. Tudo isso se desdobra no destaque a ser conferido à produção de novas formas de subjetivação, que se constituíram como efeitos privilegiados e artefatos dessa retórica, reguladas que são pelas relações de força que imantam o campo do poder.

Dito isso, necessária agora é a leitura preliminar de alguns jogos de linguagem e de verdade da palavra assédio na atualidade. É o que se fará a seguir.

\section{SEXUAL E MORAL}

Inicialmente, é preciso evocar que a palavra assédio não é absolutamente nova no vocabulário do Ocidente, como se pode verificar facilmente pela leitura superficial de alguns dicionários. O Nouveau petit le Robert, dicionário da língua francesa, nos informa que o verbo harceler existe desde 1493 e que o substantivo harcèlement desde 1632. O Dicionário Houaiss, da língua portuguesa, afirma que a palavra surgiu no português no século XIII, proveniente do latim vulgar. A palavra em questão é, portanto, de origem latina, inscrevendo-se na tradição portuguesa na passagem da Idade Média para tempos modernos.

Portanto, apesar de já existir há muito tempo, foi somente nos últimos anos que a palavra assédio passou a ocupar um lugar destacado no imaginário contemporâneo, incidindo profusamente na mídia e se inscrevendo também no contexto da produção teórica, seja das ciências sociais e jurídicas, seja da psicopatologia e da psicanálise. Com isso, o seu campo semântico se transformou, de maneira que se produzissem novas significações. Em decorrência disso, foram forjados novos jogos de linguagem e de verdade sobre a palavra assédio.

Com efeito, se até poucos anos atrás a palavra assédio se referia estritamente ao registro "sexual", estando referida aqui precisamente às mulheres - que se queixavam ostensivamente dos homens que se dirigiam a elas com um discurso sexualmente indecente e indecoroso que as humilhava, por se sentirem reduzidas 
à condição de objeto sexual -, nos últimos tempos, a palavra assédio se transformou no seu campo de significação. Nesse, o assédio sexual foi reinterpretado e inscrito num outro contexto discursivo. Com isso, foi reduzido o seu campo de sentido e sua abrangência anteriores, à medida que passou a ser considerado como um caso particular de categoria mais abrangente de assédio. O que se enuncia hoje como fundamental é a existência do assédio "moral", no qual alguém é solapado na sua segurança identitária e esvaziado nas suas potencialidades sociais e psíquicas de ser. Tudo isso acontece em diversos contextos sociais, dentre os quais se destaca largamente o espaço social do trabalho. $\mathrm{O}$ assédio sexual seria, enfim, um caso particular do assédio moral.

Num recenseamento sumário das queixas de assédio moral nos lugares de trabalho, uma referência comum se destaca, qual seja, o uso ostensivo da hierarquia funcional. Assim, um superior qualquer se vale de sua posição institucional para atingir e prejudicar um funcionário subalterno, que é minado então nas suas prerrogativas. Este é solapado nas suas atribuições e na sua posição institucional. Além disso, é freqüiente a participação de outros funcionários subalternos no processo desencadeado pelos superiores, que se associam a esses no esvaziamento da potencialidade institucional da figura do atingido.

Entretanto, o mesmo processo pode se realizar também no nível horizontal e não apenas no vertical. Assim, o assédio moral pode se constituir no escalão superior de uma organização social, nas disputas de poder entre iguais que se valem de táticas escusas para a invalidação do oponente. Da mesma forma, os funcionários subalternos de uma dada organização podem prejudicar a posição de um colega, pela desestabilização ostensiva de suas condições sociais de trabalho.

Nessas diferentes situações evocadas os efeitos psíquicos são similares, contudo, são marcados pela presença do "horror". Isso porque implicam sempre a desestabilização da "identidade" e a perda dos signos de segurança da personagem em questão. A identidade em pauta aqui se refere, é claro, aos registros social e psíquico. Em decorrência disso, produz-se uma transformação crucial na economia psíquica do narcisismo do personagem atingido, que conduz freqüentemente à depressões severas e à destruição de sua imagem. Como o processo é geralmente sorrateiro e progressivo, a auto-estima da personagem afetado se esvazia pouco a pouco, conduzindo de uma maneira quase inapelável à sua destruição institucional. Não tendo com quem contar e confiar, no contexto do trabalho, aquela pode freqüentemente se atribuir, no fantasma, toda a responsabilidade pelo que ocorre. Porém, sem ter signos seguros no real para sustentar nada, a personagem em questão é colocada numa experiência-limite, marcada que é pela incerteza total e pela insuportabilidade psíquica (HIRIGOYEN, 1998).

A cena do assédio moral assume então características francamente perversas, na qual a personagem atingida se sente envolvida numa trama diabólica, sem saber muito bem por que foi lançada nisso. É bastante possível que a estrondosa disseminação do significante "teoria da conspiração", na contemporaneidade, se articule com isso, sendo um jogo de verdade que é derivado do jogo de verdade 
sobre o assédio. De qualquer forma, a cena do assédio acaba por lançar a personagem numa condição de paralisia mental e na impossibilidade de agir, à medida que as suas reações são esvaziadas de qualquer sentido pelos demais participantes da trama. Não existindo qualquer reconhecimento dos outros pelo que experimenta a personagem visada, essa não sabe mais qual é a fronteira entre o que imagina e o que é real. Em consequiência disso, não é incomum que esta acredite que esteja enlouquecendo, já que não são evidentes as razões para a perseguição que vivencia. O colapso psíquico, enfim, é a resultante maior desta experiência inquietante.

Nesse contexto, as licenças de trabalho por motivos de saúde são bastante comuns, destacando-se amplamente as que são por motivos psiquiátricos. Dentre esses, as depressões e os quadros psicossomáticos são certamente dominantes. É evidente que as licenças psiquiátricas reforçam ainda mais a experiência de destruição social da personagem afetada, confirmando a posteriori a desconfiança dos superiores e dos colegas sobre a credibilidade e a competência funcional desta, realimentando no imaginário as idéias da trama diabólica e da "conspiração".

Nos registros ético e social, em contrapartida, é evidente o silenciamento da "solidariedade" como valor, na leitura deste processo como uma totalidade. No que concerne a isso, deve-se sublinhar não apenas a forma pela qual os superiores agem para atingir um subordinado, mas principalmente a colaboração de subalternos, do mesmo escalão e status, com a chefia na condução desse processo. O que revela não apenas o alto nível de competição existente no mercado e nas relações de trabalho na sociedade contemporânea, como também o "medo" que se dissemina como uma verdadeira peste nas instituições, no que tange à possibilidade de perda de emprego pelos trabalhadores (DEJOURS, 1998). Seria o medo da perda do trabalho, portanto, o que produziria a quebra dos laços de solidariedade entre os subalternos, no contexto da atual economia neo-liberal, sendo ainda as condições sociais de funcionamento dessa que alimentariam a onipotência dos superiores hierárquicos diante de seus comandados, como ainda veremos posteriormente neste ensaio.

A problemática que se impõe agora é a razão pela qual esta palavra se popularizou tanto e se inflou desmesuradamente, transformando-se mesmo numa queixa freqüente na sociedade contemporânea. Isso não é algo evidente, o que revela a existência de um enigma a ser decifrado pelos teóricos que disso se ocupam. Vale dizer, a minha indagação crucial agora é sobre a condição concreta de possibilidade da inflação assumida hoje por este jogo de linguagem do assédio, que define um campo trivial de queixas e de interpretações comuns que se encontram presentes nas relações sociais e principalmente no contexto do trabalho, quando anteriormente tal jogo de linguagem não se destacava ostensivamente no campo do discurso e tinha um uso coloquial relativamente restrito.

O que se pretende agora, então, é delinear os solos social e histórico sobre os quais foram renovados os jogos de linguagem e de verdade em torno do assédio. 


\section{DO REGISTRO POLÍTICO AO MORAL}

A leitura dos dicionários indica algo bastante interessante sobre a palavra assédio. Com efeito, se esta palavra se inscrevia originalmente nos registros "político" e "militar", sendo um significante que se cristalizou num campo semântico voltado para estratégias de domínio político e de práticas de guerra, foi apenas posteriormente que assumiu significações nos registros "moral" e "psíquico", como "atormentar", "fustigar", "importunar", "molestar", "perseguir", etc. Este último campo semântico do assédio é mais familiar para nós do que o primeiro, sendo esse, pois, mais distante de nossas representações sociais.

Assim, quando nos referimos aos assédios sexual e moral, o que se coloca para nós imediatamente é algo da ordem da ofensa ética e do ataque à identidade psico-social, inscrevendo-se, então, nos registros moral e psíquico. A articulação dessas experiências num contexto político é algo bem mais distante para nós, exigindo, pois, um esforço interpretativo bem mais sutil, para que se possa efetivamente enunciar a presença de algo que se inscreve no registro político propriamente dito. $\mathrm{O}$ discurso feminista, é claro, procurou realizar este apelo ao inscrever o assédio sexual no registro político, subsumindo para isso o registro moral ao político. Da mesma forma, o assédio moral, no campo social contemporâneo das relações de trabalho, pôde ser traduzido para o registro político, indicando a articulação entre os dois registros em pauta, como ainda veremos neste ensaio.

Dessa maneira, pode-se supor aqui, como uma hipótese inicial de trabalho, que a passagem do primeiro registro para o segundo se realizou na modernidade, na passagem do século XVIII para o século XIX. Com isso não quero dizer que o primeiro registro semântico tenha deixado de existir, mas que foi colocado numa posição subalterna e latente diante do segundo que então se inflacionou. Em contrapartida, é o sentido originário da palavra que funciona como regulador dos registros moral e psíquico do assédio, como vou sustentar ainda aqui numa segunda hipótese de trabalho. Seria em decorrência disso que os assédios sexual e moral puderam também ser interpretados historicamente no registro político, como indiquei acima.

Vale dizer, a palavra assédio se constituiu nos registros político e militar no final da Idade Média, expandindo-se no Renascimento e nos primórdios dos tempos modernos. Portanto, este jogo de verdade originário sobre o assédio é a contrapartida discursiva da ética do humanismo e da constituição do Estado como instância de "soberania" política. As fronteiras do Estado absolutista tinham de ser mantidas incólumes pelos exércitos do Rei, para que o território do Estado não fosse assediado pelos inimigos e ameaçado na sua soberania.

Portanto, a problemática da soberania é fundamental para a interpretação dos jogos de verdade sobre o assédio. É justamente pela alusão à soberania do poder político que o sentido originário da palavra assédio funcionou como regulador latente dos novos sentidos - moral e psíquico - que a palavra veio a assumir e que se inflacionou posteriormente, mas que se constituiu apenas na modernidade propriamente dita. 
Do estrito ponto de vista político a modernidade foi caracterizada seja como república seja como democracia, contrapondo-se sempre ao absolutismo anterior. Nesta passagem se constituiu a figura política da "cidadania" e o seu correlato, qual seja, o discurso dos direitos do cidadão. Estes se articulavam no conceito de Estado do direito e do cidadão, isto é, do Estado que deveria garantir os direitos desse. Foi apenas nessa viragem histórica que o campo semântico da palavra assédio foi inserida nos registros moral e psicológico, à medida que o desdobramento desses registros foi a contrapartida da figura política do cidadão, como portador que seria de direitos inalienáveis, que deveriam ser garantidos pelo Estado.

Na perspectiva antropológica a modernidade foi caracterizada pela constituição do "individualismo", como enunciou Dumont (1977, 1983). Forjou-se aqui o conceito do indivíduo como "valor", que se enunciou nos parágrafos iniciais das constituições oriundas da Revolução americana e da Revolução francesa. Vale dizer, se o conceito de indivíduo como empiricidade existia desde a Antiguidade, foi apenas na modernidade que o indivíduo como valor foi transformado na unidade básica da sociedade, isto é, no seu fundamento político e ético. Com efeito, a sociedade passou então a ser concebida como uma "associação" de indivíduos. Com isso, o Ocidente foi transformado de ponta-cabeça, deslocando-se de um paradigma holista para um outro que era agora individualista.

Parece-me, então, que a transformação do sentido da palavra assédio, a que já fiz alusão, se inscreve nesta mudança sociopolítica radical. Nesse contexto, a palavra ganha não apenas um sentido outro nos registros moral e psicológico, como também o assédio é ainda negativamente denotado. Isso porque "importunar", "molestar" e "perseguir" alguém consubstancia uma ação moral nefasta e negativa, se considerarmos o ideário dos direitos inalienáveis do cidadão, que devem ser sempre resguardados e protegidos pelo soberano. Além disso, é a soberania inalienável do indivíduo, como valor supremo que teria ser sempre mantida custe o que custar, contra a invasão do território inviolável de sua intimidade.

Assim, na aurora da modernidade o indivíduo como cidadão foi transformado no fundamento da sociedade, de forma que não protegê-lo enquanto tal, como valor, é atingir fatalmente o fundamento desta. Caberia ao Estado, como soberano, a função de salvaguarda dos direitos do cidadão. Portanto, o sentido moral e psicológico do assédio, que se enunciou neste contexto, remete, de maneira latente, para a soberania do Estado como garantia que este deve ser para a manutenção dos direitos dos cidadãos como indivíduos. O que nos revela ainda como é o jogo inicial de verdade sobre o assédio, o que regula, de maneira implícita, o jogo de verdade posteriormente constituído, mas indicando, ao mesmo tempo, o deslocamento e o reordenamento do seu campo semântico.

Isso tudo nos indica que a universalidade dos direitos se enunciou aqui como um "ideal" a ser atingido pelos cidadãos, dada a existência de uma flagrante "hierarquia social" nas sociedades ocidentais e nas relações entre os Estados-nação no cenário internacional. A hierarquia, como realidade de "fato" existente no Ocidente, opunha-se ao ideário igualitário do "direito", como pressuposto que esse era da modernidade política. Tais hierarquias se fundavam em mecanismos 
de poder e de dominação política existentes no campo das relações sociais reais, que coexistiam com o ideário igualitário. Este em contrapartida, agenciava os movimentos sociais que demandavam sempre a ampliação da igualdade e a redução das hierarquias.

A construção do Estado de bem estar social foi um dos pontos de chegada dessa longa marcha rumo à igualdade, forjado no continente europeu no final da segunda Guerra Mundial. Da mesma forma, as revoluções socialistas que marcaram o século XX pretendiam realizar a quebra das hierarquias sociais e a promoção do ideário igualitário. Nesses diferentes contextos, a soberania de cada Estado-nação deveria realizar a gestão dos ideais igualitários e ser a garantia para o cumprimento dos direitos dos cidadãos.

De qualquer maneira, isso nos mostra que era a soberania do Estado quem deveria garantir a igualdade e a universalidade dos direitos para os cidadãos. A implicação evidente do Estado nas estratégias de dominação, no entanto, era a condição concreta de possibilidade das hierarquias sociais, como se sabe. Com isso, o Estado não podia realizar o que se esperava efetivamente dele e o que ele deveria de fato fazer. Por isso mesmo, as estratégias revolucionárias socialistas que dominaram o cenário do Ocidente no século passado pretendiam assumir o controle do aparelho do Estado, para que esse pudesse finalmente realizar o ideário igualitário que o Estado capitalista e burguês não poderia empreender. Enfim, mesmo aqui a soberania do Estado nunca foi colocada em questão, mas deveria funcionar de outra maneira, para que a garantia dos direitos dos cidadãos e o ideário igualitário pudessem de fato existir.

Porém, como a soberania do Estado não foi colocada em questão pelos movimentos sociais na modernidade, como garantia que deveria ser dos direitos dos cidadãos, o jogo de verdade do assédio se enunciava nos registros moral e psicológico, mantendo os registros político e bélico no nível latente. Assim, qualquer indivíduo deveria ter direito à manutenção da privacidade e da intimidade, mantendo, além disso, suas garantias como cidadão no sentido amplo do termo, não podendo ser invadido no território sagrado de seu valor como sujeito. Por isso mesmo, não poderia ser "molestado", "atormentado" e "perseguido", já que assim não estaria sendo reconhecido como indivíduo propriamente dito, pois perderia o seu valor como sujeito moral e psicológico.

\section{GÊNEROS E JOGOS DE VERDADE}

No entanto, nos anos 60 algo de fundamental foi subvertido de maneira frontal na tradição ocidental. Refiro-me agora à condição social da mulher. Isso porque a condição hierárquica inferior atribuída à figura da mulher, na sua relação opositiva à do homem, foi radicalmente colocada em questão pelos movimentos feministas. Iniciando-se nos Estados Unidos, disseminando-se em seguida para a Europa e demais continentes, a relação hierárquica entre os gêneros foi efetivamente subvertida pelo feminismo.

A construção social da figura da mulher, forjada em torno da função da maternidade e da governabilidade do espaço privado e familiar, em oposição à 
figura do homem, centrada na função econômica e na governabilidade do espaço público, não era então mais aceitável pelas mulheres, tal como tinha sido instituída no final do século XVIII, com o argumento de que seu destino seria infalivelmente a maternidade, em decorrência da especificidade de sua constituição biológica e moral. No contexto histórico e social do discurso da igualdade de direitos dos cidadãos, forjada no século XVIII, os gêneros sexuais deveriam ter sido equiparados, rompendo com a longa tradição patriarcal constituída desde a Antiguidade. No entanto, a hierarquia foi mantida entre os gêneros com a formulação de que existiam identidades biológicas e morais diferenciadas entre esses, que destinavam as mulheres à maternidade e ao espaço familiar (LAQUEUR, 1992).

É claro que foi atribuída uma outra modalidade de poder às mulheres desde o século XVIII, não obstante a manutenção da hierarquia presente na tradição patriarcal. Por isso mesmo, me referi acima à governabilidade do espaço privado e familiar, até então atribuído às mulheres (BIRMAN, 2001). Como nos disse Foucault, neste contexto histórico que foi o solo para a constituição do "biopoder" e da "biohistória", a figura da mulher como mãe foi um instrumento e um aliado fundamental do poder médico, no processo de medicalização do social que então se empreendeu. O projeto político moderno, de que a "qualidade de vida" da população seria a fonte maior de riqueza das nações, foi realizado com a colaboração efetiva da figura da mulher como mãe, que no campo da família possibilitava os novos desenvolvimentos sociais dos poderes médico e pedagógico.

Como se sabe, o argumento diferencial que mantinha ainda a tradicional hierarquia entre os gêneros sexuais foi forjado pelos pensadores mais eminentes do final do século XVIII e do início do século XIX, sendo ainda devidamente construído e sancionado pela medicina. Com efeito, de Rousseau a Hegel e Comte, passando por Kant, os mais prestigiosos filósofos de então sustentaram o argumento diferencial e se opuseram à efetiva igualdade entre os gêneros sexuais. Foi mantida, assim, em outras bases agora, a hierarquia entre os gêneros, constituída desde a Antiguidade grega.

Porém, isso contrariava o ideário igualitário forjado pela Revolução Francesa. Com efeito, as mulheres foram colocadas numa subalternidade hierárquica em relação aos homens, reduzidas que foram à condição de ser de natureza e não de cultura. Pela marca diferencial que as caracterizava, em que as potencialidades afetivas eram bem mais poderosas do que as intelectuais, as mulheres estavam fadadas ao acolhimento maternal. Por isso mesmo, não podiam ter acesso a certos direitos, usufruídos apenas pelos homens. Alguns dos direitos dos cidadãos não lhe foram atribuídos, tais como, o direito do voto e o de ter acesso ao mercado de trabalho. Em decorrência disso, desde o sécuulo XIX os movimentos feministas buscavam estabelecer a igualdade de direito entre os gêneros, procurando romper, assim, com a hierarquia estabelecida pela antiga tradição do patriarcado e que teve finalmente nos anos 60 sua ruptura mais significativa.

Constituiu-se aqui a revolução mais radical do século passado, segundo alguns autores, dentre as muitas que aconteceram. Isso porque, segundo a fórmula ao mesmo tempo incisiva e sintética enunciada por Castoriadis, tal revolução se 
realizou no exíguo espaço familiar, delineado entre o quarto e a cozinha, dilacerando assim o fundamento territorial e funcional da longa tradição do patriarcado. Porém, essa desconstrução de uma dimensão bastante precisa do espaço social teve o poder de subverter este na sua totalidade, já que relançou as cartas do jogo dos gêneros sexuais, que estava codificada até então pela oposição entre as governabilidades privada e pública. Empreendeu-se aqui, pois, uma revolução em intenção e em extensão, de maneira que a figura da mulher pôde se assumir plenamente então e exigir ser reconhecida como sujeito do direito, já que até então esses direitos eram relativos e limitados.

Foi somente nesse contexto histórico que se constituiu o jogo de verdade do assédio sexual. Isso porque esse jogo pôde ser forjado somente quando a figura da mulher se enunciou e exigiu ser reconhecida como sujeito pleno do direito. Com efeito, as mulheres passaram desde então a reagir ao serem colocadas na condição de objeto sexual (natureza) pelos homens, respondendo a essa desqualificação identitária em diferentes instâncias sociais e políticas, inclusive no plano jurídico. Milhares de processos judiciais aconteceram desde então, envolvendo as instituições da família, do trabalho e da universidade. As transformações radicais ocorridas nos códigos sexual e conjugal, desde os anos 60 , foram também disso diretamente derivadas.

Tudo isso porque, exigindo ser agora reconhecida como sujeito pleno do direito (cultural), a figura da mulher não mais queria ser tratada como cidadão de segunda categoria (natureza), como ocorria desde a Antiguidade e demandava agora uma outra modalidade de respeito, isto é, o reconhecimento social de sua efetiva condição de igualdade com os homens. Portanto, o jogo de verdade do assédio sexual se materializava então como discurso em toda e qualquer situação na qual a figura da mulher podia ser desqualificada no seu valor, pela simples condição de ser mulher e por não ser acolhida como sujeito do direito.

Este processo gerou um campo bastante controverso de embates sociais entre os gêneros sexuais, como se sabe, principalmente na sociedade norte-americana. Isso porque qualquer paquera de um homem para com uma mulher e qualquer tentativa erótica de sedução poderia ser transformada numa queixa policial e jurídica de assédio sexual. A sedução foi então transformada virtualmente na figura jurídica do crime, no caldo de cultura puritano da ética protestante.

Porém, tudo isso apenas torna mais evidente que o jogo de verdade do assédio sexual apenas se forjou no contexto histórico e político da luta social das mulheres para se transformarem plenamente em sujeito do direito, rompendo com a tradição patriarcal e exigindo os mesmos direitos conferidos até então apenas aos homens. Portanto, foi no bojo desta demanda de reconhecimento que se forjou este jogo de verdade eminentemente pós-moderno.

Não se pode perder de vista aqui, no entanto, que foi somente nesse contexto histórico e político de luta pelos direitos realizados pelas mulheres que as conotações originárias do jogo de verdade do assédio foram atualizadas e colocadas novamente na cena do social. Vale dizer, se os registros político e bélico do jogo de verdade do assédio se deslocaram de sua posição latente e virtual, passan- 
do a se inscrever agora de maneira patente no campo do jogo de verdade moderno, constituído pelos registros moral e psicológico, isso indica claramente que é a problemática da soberania e do poder que está aqui em pauta, regulando secretamente o moderno jogo de verdade do assédio.

Vale dizer, foi apenas quando a figura da mulher se colocou finalmente como sujeito e não apenas como assujeitada à figura do homem, rompendo definitivamente, então, com sua subalternidade hierárquica, que ela passou também a exigir o reconhecimento efetivo de seus novos lugares sociais pelo Estado, como detentor que este era da soberania. O corpo feminino foi, assim, transformando-se numa cidadela soberana, a ser defendida com todas as armas possíveis de serem usadas diante do inimigo, sejam estas políticas ou militares, isto é, nos registros da retórica e da força, de acordo com as circunstâncias sociais em jogo.

A promoção política do jogo de verdade do assédio sexual desdobrou-se e implicou também em novas formas de subjetivação para os diferentes gêneros sexuais. Desde então, as figuras do homem e da mulher não se representam mais da mesma maneira que anteriormente. Uma outra alquimia entre a passividade e a atividade passou a ser a matéria-prima narcísica e identitária dos diferentes gêneros sexuais, que refundou de uma outra forma as categorias de governabilidade pública e privada, tal como eram declinadas no moderno jogo de verdade do assédio.

Contudo, o que foi aqui esboçado para a subversão da relação entre os gêneros sexuais não se restringe apenas a este campo do social. O processo em pauta se realiza também, mantendo as suas especificidades, é claro, em outros campos do social nos quais a hierarquia é colocada também em questão. É o que vou propor a seguir, de maneira sumária.

\section{Hierarquias}

$\mathrm{O}$ que estou querendo enunciar agora é que este mesmo processo de desconstrução e de subversão de certas hierarquias sociais pode ser talvez generalizado na sua operacionalidade e funcionalidade políticas. O que indiquei até aqui, no que concerne às mulheres, poderia ser demonstrado em relação a outros campos de confronto no campo social, nos quais a "naturalização" de uma dada hierarquia social seja colocada em questão. Para que esta desnaturalização aconteça, o que implica sempre no solapamento da hierarquia social estabelecida, o registro moral e psicológico do jogo de verdade do assédio é dilacerado, pois aparece, logo em seguida, o registro político e bélico que estava até então latente e que regulava o registro manifesto. Isso porque o indivíduo se apresenta agora como cidadão propriamente dito, como sujeito político do direito, transcendendo em muito suas dimensões moral e psicológica.

Nessa perspectiva, o racismo seria um exemplo rico a ser investigado, na medida que supõe sempre a existência de uma hierarquia natural entre as diferentes raças, principalmente dos brancos em relação aos negros. Autoriza-se, dessa maneira, qualquer modalidade ostensiva de assédio daqueles diante desses, à medida que a figura do negro não é reconhecida plenamente como sujeito do direito 
e como cidadão. Isso acontece tanto em sociedades nas quais o racismo é camuflado e em que existe uma suposta democracia racial, como no caso do Brasil, ou ostensivo, como é o caso dos Estados Unidos e da África do Sul. De qualquer maneira, a ruptura com a hierarquia social que foi naturalizada e cristalizada se realiza sempre de forma violenta, isto é, através de práticas política e bélica, pelas políticas de ação afirmativa. Seria através dessas que os negros se enunciam e exigem ser reconhecidos como sujeitos plenos do direito, pelo Estado, como instância detentora que este é da soberania. Com isso, os negros buscam ser reconhecidos, assim como as mulheres, como seres de cultura e não de natureza, com a mesma igualdade de direitos dos brancos. Procuram contrapor-se assim, aos preconceitos e ao assédio de que são objeto, nos registros social, político e econômico.

Não entrarei agora nisso aqui, pois me desviaria dessa breve genealogia do assédio que pretendo agora desdobrar. De qualquer maneira, o que a problemática racial já indica de maneira eloqüente é que o jogo de verdade do assédio sexual se inscreve num jogo de verdade mais amplo que é o do assédio moral. É o que veremos agora, para concluir este ensaio.

\section{SOBERANIA PERDIDA}

A constituição do jogo de verdade do assédio moral é bem mais recente no Ocidente. É sempre disso que se fala agora, cada vez mais, quando se enuncia algo sobre o assédio e que é por este viés que essa palavra se inflaciona no nosso vocabulário. Depois das múltiplas intempéries e queixas das mulheres em torno do assédio sexual, é certamente o assédio moral que se inscreve agora na cena da sociedade contemporânea. Na disseminação atual do assédio moral, o assédio sexual se inscreve agora como um caso particular daquele, como já disse inicialmente.

Entretanto, a condição histórica de possibilidade para a sua emergência é de outra ordem, sendo esta a minha última hipótese de trabalho neste ensaio. Isso porque o que está aqui em pauta é a descrença em relação à soberania, que se mantinha incólume até então, pois se apelava sempre para o poder do Estado soberano para coibir o assédio e defender os direitos do cidadão importunado. Ou, então, quando não se acreditava mais na soberania do Estado, este era tomado de assalto pelos grupos dos desprivilegiados nos seus direitos, num processo revolucionário, com a intenção de instituir, finalmente, uma soberania que reconhecesse a igualdade de direitos para todos os cidadãos. Porém, é a incerteza radical quanto a isso que se coloca agora com toda a força, de maneira inédita na nossa tradição.

Assim, não se pode separar a inflação relativamente recente do jogo de verdade do assédio moral do amplo, geral e irrestrito processo de mundialização que nos envolve hoje como um todo. Isso porque este implica, antes de mais nada, a desconstrução ostensiva da soberania do Estado-nação. Em seguida, esta desconstrução acarreta ainda a perda de autonomia do registro político, que passa a ser imediatamente regulado pelo registro da economia. Este passa a dar, agora, 
as cartas dos jogos do poder, de maneira que o mercado e os fluxos voláteis do capital colocam na berlinda a soberania das nações e dos Estados.

O Estado, como garantia para o reconhecimento do cidadão e do sujeito do direito, se quebra de maneira progressiva, não podendo mais as individualidades contarem com isso de maneira incondicional para lhes oferecer um suporte efetivo. Em nome da produtividade e da eficácia, isto é, em nome da acumulação e disseminação do capital transnacional, tudo é passível de acontecer; as individualidades não contam mais com as garantias que o Estado-nação até então lhes outorgava. Como o capital não tem fronteira e se regula apenas pela sua multiplicação e disseminação, não existem mais obstáculos tangíveis capazes de impedir o seu fluxo na economia neo-liberal atual. Em decorrência disso, as fronteiras do Estado-nação tornam-se porosas, à medida que os territórios das nações passaram a ser redesenhados em função da circulação do capital e das redes de comunicação.

A incerteza e a imprevisibilidade passam a marcar a existência das individualidades, à medida que não existem mais esses suportes absolutos em que se apoiar, para preverem as suas vidas no futuro. Com as perdas das garantias e da segurança - no que se refere ao mercado de trabalho - pela gestão neoliberal da economia, o Estado do bem estar social começa a ser progressivamente desmantelado. Tanto na Europa quanto na América Latina, passando por outros pontos do planeta, o mesmo processo social se realiza. A segurança das pessoas nos postos de trabalho que ocupam não tem mais salvaguardas jurídicas consistentes, já que podem ser demitidas a qualquer momento, por razões de produtividade e de equilíbrio orçamentário das empresas. A insegurança institui-se, então, em escala planetária. Com isso, o fantasma da perda do lugar social expande-se em escala global, não apenas nos países onde o Estado de bem-estar social era uma referência fundamental, mas em toda parte.

Foi devido à leitura acurada desse novo contexto social, no que se refere às condições atuais do mercado de trabalho, que Sennet (1999) formulou o conceito de "corrosão do caráter", como marca original que seria da individualidade contemporânea. Essa, com efeito, não pode mais construir para si programas e estratégias de longo prazo para a sua existência, fundados numa ética consistente. Isso porque a individualidade contemporânea, marcada pela incerteza e pela imprevisibilidade, deve sempre improvisar e se adaptar às transformações rápidas das regras do jogo para sobreviver, sem contar com garantias jurídicas e institucionais sólidas. Constituiu-se, assim, uma outra forma de subjetivação, na qual o caráter de uma determinada individualidade, a que se evidenciava pela presença de uma invariante que permeava a totalidade de sua existência, passa a ser substituído por normas funcionais e contextuais.

Foi justamente nesse contexto histórico, político e social que o jogo de verdade do assédio moral foi construído com todas as suas peças, remetendo à insegurança radical das individualidades, ameaçada que são de perda de seu lugar social. Tudo isso coloca o fantasma da morte social no primeiro plano da cena 
política contemporânea. Por isso mesmo, a problemática da identidade ocupa uma posição tão fundamental na experiência social e psíquica das pessoas que são objeto e alvo do assédio, pois a quebra da identidade se refere drasticamente aqui à perda da noção de pertencimento ao corpo social e à exclusão do indivíduo do espaço social. É a idéia de cidadania e do seu correlato, isso é, o discurso dos direitos do cidadão, o que está aqui em pauta.

Ao lado disso, a competição entre os indivíduos atinge limiares espetaculares, já que é a luta pela sobrevivência no mercado de trabalho o que está em questão nesta disputa. Com isso, a solidariedade como valor ético e político tende ao desaparecimento, como indiquei no início deste ensaio, sendo tal perda de solidariedade uma outra maneira de se falar na atual "corrosão do caráter" enunciada por Sennet.

Porém, a lógica que sustenta a totalidade desse processo é a perda progressiva da soberania pelo Estado, que fica entregue aos interesses dos fluxos do capital em escala internacional. Com isso, o Estado como figura de "mediação", posição que ocupava no espaço social da modernidade e que oferecia formas de proteção para os cidadãos, começa a ser ostensivamente desconstruído. É a perda desse poder de mediação que permite que os superiores de uma empresa se autorizem a fazer o que querem e bem entendem com os subalternos, num evidente abuso de autoridade. Também é por causa disso que os demais subalternos se aliam ao chefe e não ao colega assediado, já que não podem mais acreditar e confiar na mediação do Estado para limitar efetivamente tal abuso de autoridade, preferem se associar ao superior para manterem seu lugar institucional e não serem, assim, excluídos definitivamente também do espaço social.

Assim, como enunciou Beck (1995), se estamos inscritos hoje numa "sociedade de risco", isto é certamente a contrapartida da perda progressiva da soberania do Estado e do seu poder de mediação, que lança o conjunto dos indivíduos numa condição social original, marcada que é pela imprevisibilidade, incerteza e insegurança. $\mathrm{O}$ assédio moral, como jogo de verdade e prática de poder que é da sociedade contemporânea, é uma das resultantes maiores destas articulações sociopolíticas. Por isso mesmo, como jogo de verdade, o assédio moral se dissemina e se inflaciona no imaginário da sociedade contemporânea.

$\mathrm{Na}$ atualidade, portanto, o se sentir "molestado", "perseguido" e "importunado" nos seus direitos sociais como cidadão perde a sua anterior caracterização moderna, eminentemente moral e psicológica, remetendo para a sua significação originária, na medida que os registros da política e da guerra se fazem novamente presentes, sendo estes relançados no mercado de bens simbólicos. Cada individualidade agora deve se defrontar diretamente com a sua soberania radicalmente, pois a sua cidadela privada não pode mais ser protegida pelo Estado como ocorria anteriormente. Isso porque o seu corpo, como território que é de sua privacidade e intimidade, precisa ser defendido na sua materialidade e nas suas fronteiras, custe o que custar, contra a ameaça da "morte real" e da "morte simbólica". Este é, enfim, o ponto de chegada trágico da individualidade contemporânea, pelo lugar incerto e imprevisível em que o cidadão foi lançado hoje pela sociedade de risco. 
Tudo isso nos indica que, quando na modernidade, a soberania do Estado garantia a segurança de seus cidadãos, baseado no discurso universal dos direitos, mesmo num horizonte social marcado pelas hierarquias sociais, o assédio era um jogo de verdade que se restringia aos registros moral e psicológico. A figura da individualidade se mantinha então incólume. Quando a soberania do Estado foi colocada em questão, no entanto, os registros político e bélico do assédio passaram a se revelar de maneira ostensiva e brutal no seu jogo de verdade, como nos acontece hoje de maneira flagrante, nestes tempos sombrios de salve-se quem puder.

\section{REFERÊNCIAS}

BADINTER, E. L'un et l'autre. Paris: Odile Jacob, 1986.

BECK, U. A reinvenção da política. In: GIDDENS, A.; BECK, U.; LASCH, S. Modernização reflexiva. São Paulo: Unesp, 1995.

BIRMAN, J. Gramáticas do erotismo. Rio de Janeiro: Civilização Brasileira, 2001.

DEJOURS, C. H. Souffrance em france: la banalisation de l'injustice sociale. Paris: Seuil, 1998.

HOUAISS. Dicionário Houaiss da Língua Portuguesa. Rio de Janeiro: Objetiva, 2001.

DUMONT, L. Essais sur l'individualism: une perspective anthropologique sur l’idéologie moderne. Paris: Seuil, 1983.

. Homo aequalis I. Genèse et épanouissement de l'idéologie économique.

Paris: Gallimard, 1977.

HIRIGOYEN, M. F. Le harcèlement moral. Paris: La Découverte et Syros, 1998.

KOFFMAN, S. Aberrations. Le devenir femme d'Auguste Comte. Paris: AubierFlammarion, 1970.

. Respect de femme. Paris: Galilée, 1972.

FOUCAULT, M. Surveiller et punir. Paris: Gallimard, 1974.

. Les techonologies de soi-même. In: Dits et écrits. Paris: Gallimard, 1994.

v. 4.

. La volonté du savoir. Paris: Gallimard, 1976.

LAQUEUR, T. La fabrique du sexe. Paris: Gallimard, 1992.

ROBERT LE P. N. Dictionnaire de la langue française. Paris: Dictionnaires Le Robert, 1994. 
SENNET, R. A corrosão do caráter: conseqüencias pessoais do trabalho no novo capitalismo. Rio de Janeiro: Record, 1999.

WITTGENSTEIN, L. Investigations philosophiques. In: Tractatus logicophilosophicus suivi de Investigations philosophiques. Paris: Gallimard, 1961.

Recebido em: novembro/2004 Aceito em: março/2005 